\title{
PENGARUH PEMBERIAN KITOSAN DALAM RANSUM TERHADAP PERFORMA AYAM ARAB SILVER
}

\section{The Effect of Chitosan in Ration on the Performance of Silver Arabic Chickens}

\author{
Eli Sahara, Sofia Sandi, Fitra Yosi, Robi Alexa \\ Jurusan Teknologi Industri Peternakan, Fakultas Pertanian, Universitas Sriwijaya \\ J1. Raya Palembang-Prabumulih KM.32. Indralaya Ogan Ilir 30662 \\ Sumatera Selatan, Indonesia
}

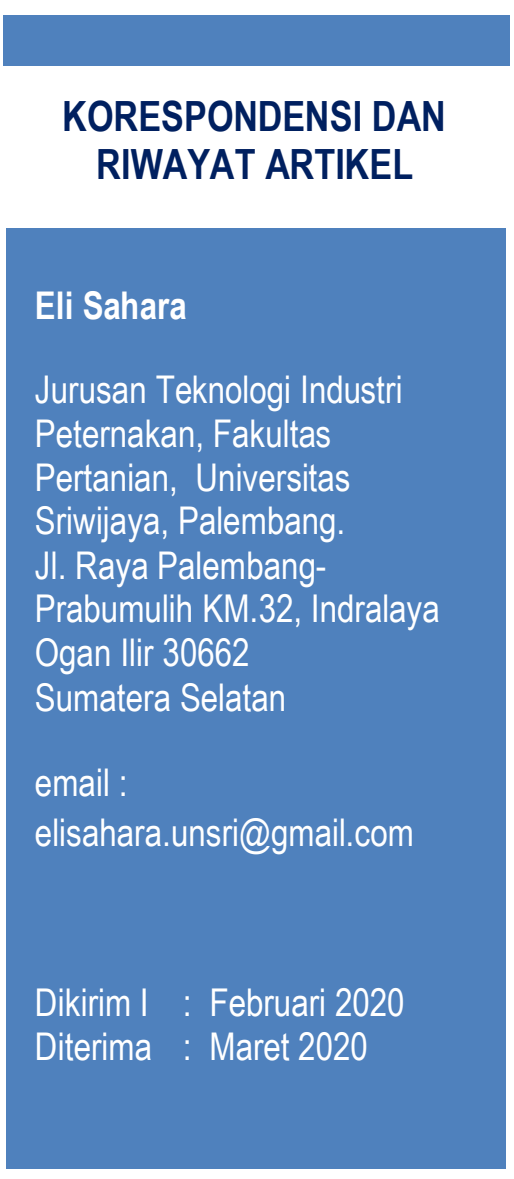

\begin{abstract}
ABSTRAK
Ransum berkualitas dibutuhkan dalam peningkatan kinerja dan produkstivitas. Salah satu upaya peningkatan kualitas ransum adalah dengan penambahan kitosan, karena kitosan merupakan serat hewan tidak toksik dan dapat bermanfaat sebagai prebiotik. Tujuan penelitian adalah meningkatkan peforma ayam Arab Silver dengan pemberian kitosan dalam ransum. Penelitian menggunakan rancangan Rancangan Acak Lengkap (RAL) dengan 6 perlakuan, 5 ulangan dan masing-masing ulangan terdiri dari 2 ekor ayam, sehingga jumlah ayam yang digunakan adalah 60 ekor. Perlakuan penelitian adalah $\mathrm{R} 0=$ Ransum Basal $/ \mathrm{RB}$ (kontrol) $\mathrm{R} 1=$ $\mathrm{RB}+0,5 \%$ kitosan, $\mathrm{R} 2=\mathrm{RB}+1 \%$ kitosan, $\mathrm{R} 3=\mathrm{RB}+1,5 \%$ kitosan $\mathrm{R} 4=\mathrm{RB}+2 \%$ kitosan, $\mathrm{R} 5=\mathrm{RB}+2,5 \%$ kitosan. Parameter yang diukur adalah peforma produksi seperti konsumsi ransum, produksi telur (hen day) dan konversi ransum. Hasil penelitian menunjukkan bahwa pemberian perlakuan kitosan menunjukkan perbedaan yang tidak nyata terhadap konsumsi ransum, produksi telur (hen day) dan konversi ransum $(\mathrm{P}>0,05)$. Kesimpulan penelitian ini adalah pemberian kitosan dalam ransum selama masa penelitian 7 minggu memberikan rataan nilai performa produksi yang berimbang.
\end{abstract}

Kata kunci : kitosan, ransum, performa, ayam arab

\section{ABSTRACT}

Quality ration is needed to improve performance and productivity. One effort to improve ration quality is the addition of chitosan, because chitosan is a non-toxic animal fiber and can be 
useful as a prebiotic. The purpose of this study was to improve the performance of Arab Silver chicken by providing chitosan in the ration. The study used a completely randomized design (CRD) with 6 treatments, 5 replications and each test consisted of 2 chickens, so the number of chickens used was 60 . The research treatments were $R 0=$ Basal Ration $/ R B$ (control) $R 1=R B$ $+0.5 \%$ chitosan, $R 2=R B+1 \%$ chitosan, $R 3=R B+1.5 \%$ chitosan $R 4=R B+2 \%$ chitosan, $R 5=R B+2.5 \%$ chitosan. The parameters measured were performance indicators such as feed consumption, egg production (hen day) and feed conversion. The results showed that the administration of chitosan treatment showed no significant differences in ration consumption, egg production (hen day) and feed conversion (P>0.05). The conclusion of this study is the provision of chitosan in the ration during the 7 week study period provides a balanced average production performance.

Keywords: Chitosan, Ration, Performance, Arabic Chicken

\section{PENDAHULUAN}

Produktivitas ternak unggas sangat dipengaruhi oleh kualitas ransum yang diberikan. Ransum harus mngandung nutrien yang cukup untuk kebutuhan hidup pokok dan produksi. Oleh sebab itu kualitas ransum harus dijaga dari kontaminasi jamur dan mikroorganisme mulai dari penyusunan hingga lamanya penyimpanan. Berhubungan dengan hal tersebut, kualitas ransum yang dikonsumsi akan menentukan kinerja dan produktivitas dari ternak (Tanuwiria dkk., 2007; Mushawwir et al., 2010 dan 2011). Imbuhan pakan berupa feed suplemen dan feed aditif sudah biasa diberikan kepada ternak unggas untuk meningkatkan produksi. Kitosan adalah merupakan produk isolasi limbah crustacea yang berupa serat hewan, tidak beracun dan bersifat ramah lingkungan. Kitosan terdiri dari poli (2deoksi-2-asetilamin-2-glukosa) dan poli (2deoksi-2-aminoglukosa) yang berikatan secara (1-4) $\beta$-glikosidik (Tolaimatea et al.,2003 dalam Kurniasih et al., 2011). Kitosan adalah gula yang unik, karena polimer ini mempunyai gugus amin bermuatan positif, sedangkan polisakarida lain umumnya bersifat netral atau bermuatan negative. Keistimewaan kitosan ini bisa dimanfaatkan sebagai pengaman atau sebagai agen pelindung (protecting agent) bagi ternak unggas.

Ransum yang ditambah kitosan akan terjaga kualitasnya dari cemaran dan kontaminasi mikrooganisme. Ransum sehat akan menjadikan tubuh ternak sehat, sehingga kinerja produksi berjalan optimal. Kecuali itu, pemberian kitosan dalam ransum mampu meningkatkan pertumbuhan villi sehingga kecernaan dan absorbsi nutrien meningkat. Hal ini selaras dengan hasil penelitian Huang et al. (2005) dan Dinana dkk. (2019) menunjukkan bahwa absorbsi asam-asam amino esensial maupun non esensial lebih tinggi pada ayam yang diberi kitosan dari pada yang tanpa diberi kitosan. Jika demikian, maka dapat diprediksi penambahan kitosan dalam ransum selain menjaga kualitas ransum juga bermanfaat untuk peningkatan absorbsi asam amino yang dibutuhkan untuk sintesa protein sebagai bahan utama pembentukan telur.

\section{METODE PENELITIAN}

\section{Ternak Percobaan}

Ayam Arab yang digunakan adalah awal mula produksi, umur 14 minggu sebanyak 60 ekor ditempatkan dalam kandang yang sudah dilengkapi penerang, tempat makan dan minum. Ayam dipelihara selama 7 minggu. Telur dikumpul tiap hari sambil dicatat dan ditimbang untuk menentukan jumlah dan berat telur. Pencatatan dan penimbangan telur dilakukan tiap hari selama penelitian. Penelitian menggunakan Rancangan Acak Lengkap (RAL) dengan 6 perlakuan dan 5 ulangan, masing-masing ulangan terdiri dari 2 ekor ayam. Adapun perlakuan yang digunakan 
adalah : R0 $=$ Ransum Basal (tanpa kitosan), $\mathrm{R} 1=(\mathrm{RB}+0,5 \%$ kitosan $), \mathrm{R} 2=(\mathrm{RB}+1$ $\%), \mathrm{R} 3=(\mathrm{RB}+1,5 \%), \mathrm{R} 4=(\mathrm{RB}+2 \%$ kitosan $), \mathrm{R} 5=(\mathrm{RB}+2,5 \%$ kitosan $)$

Ransum perlakuan dibuat dengan cara menambahkan ransum basal dengan tepung kitosan dalam berbagai level. Dosis kitosan yang digunakan adalah bertingkat mengacu pada peneltian Sofyan et al. (2008). Parameter yang diukur ada 3 yaitu; konsumsi ransum, produksi telur, konversi ransum. Pengukuran konsumsi dimulai sejak pemberian ransum perlakuan pada itik. Itik diberi ransum sesuai kebutuhan itik per/ekor/hari dengan pola pemberian $2 \mathrm{kali}$ sehari. Ransum sisa diambil setiap pemberian ransum yang baru, dikumpul kemudian ditimbang setiap minggu. Konsumsi ransum (g) merupakan selisih dari jumlah ransum yang diberikan dengan jumlah sisa ransum (Scott et al., 1992). Produksi telur merupakan rerata produksi telur harian yang diperoleh dari pembagian jumlah produksi telur dengan jumlah ternak yang ada pada saat itu dikalikan dengan $100 \%$. Konversi ransum merupakan rasio ransum yang dikonsumsi dalam jangka waktu tertentu dibandingkan dengan bobot telur yang dihasilkan dalam waktu tertentu.

\section{Ransum}

Ransum percobaan yang digunakan disusun dengan kandungan Protein 16,63\% dan Energi Metabolis 2853,8 kkal/kg untuk periode layer sesuai kebutuhan ayam produksi yang digunakan untuk penelitian. Bahan baku yang digunakan untuk ransum basal adalah jagung 50\%, dedak padi $20 \%$, konsentrat $30 \%$. Kitosan digunakan sebagai perlakuan dengan dosis bertingkat. Kitosan yang digunakan adalah kitosan murni dari Laboratorium Teknologi Pengolahan Perikanan IPB.

\section{Analisis Statistika}

Data yang diperoleh diolah dengan analisis ragam (anova) menggunakan program SAS Windows 16. Bila terdapat pengaruh perlakuan dilakukan uji lanjut berganda Duncan (Steel and Torrie, 1991).

\section{HASIL DAN PEMBAHASAN}

\section{Pengaruh Perlakuan Kitosan Terhadap Konsumsi Ransum Ayam Arab}

Konsumsi ransum adalah banyaknya ransum yang dikonsumsi setiap ekor selama penelitian (Gambar 1). Berdasarkan analisis sidik ragam diketahui bahwa pemberian berbagai level kitosan dalam ransum tidak menimbulkan perbedaan nyata terhadap konsumsi ransum $(\mathrm{P}>0,05)$. Rataan konsumsi ransum selama 7 minggu berkisar dari 3885,66 sampai 3904,48 gram/ekor yaitu untuk perlakuan $\mathrm{R} 0=3885,66 \quad \mathrm{R} 1=3893,96$ $\mathrm{R} 2=3904,48 \quad \mathrm{R} 3=3903,42 \quad \mathrm{R} 4=3896,94$ R5= 3898,72 gram/e. Hasil penelitian menampakkan suatu bukti bahwa respon ayam mengkonsumsi ransum dengan penambahan kitosan maupun tanpa penambahan kitosan relatif sama.

Konsumsi ransum dapat dipengaruhi oleh berbagai faktor, antara lain kandungan gizi dalam pakan (Fan et al., 2008). Kebutuhan gizi ayam penelitian sudah disusun berdasarkan tuntutan ayam layer. Ransum disusun mengandung protein kasar $16,63 \%$ dan energy metabolis 2853,8 $\mathrm{kkal} / \mathrm{kg}$, sesuai kebutuhan ayam petelur produksi.

Kandungan gizi pakan secara keseluruhan disusun iso protein dan iso kalori. Sementara itu, kitosan yang diberikan dalam ransum lebih fokus ke sifatnya sebagai agen pelindung terhadap kualitas nutrisi ransum. Sifat kitosan sebagai antioksidan dan anti mikroba (Rukayadi, 2002) dapat memproteksi berubahnya kualitas ransum dari cemaran kuman atau peroksidasi lemak agar kondisi gizi ransum pada semua perlakuan tidak berubah. Berdasarkan tendensi tersebut, kitosan dianggap tidak mempengaruhi konsumsi ransum itik penelitian.

Angka konsumsi ransum ayam mulai dari 79,30 sampai 79,68 gram/ekor/hari diketahui hampir sama dengan jumlah 
konsumsi ayam petelur yang dilaporkan Sarwono (2002) bahwa konsumsi ayam Arab umur 3,5-5 bulan adalah 60-80 nyata $(\mathrm{P}>0,05)$ terhadap hen day adalah 1$)$ kitosan merupakan serat hewan yaitu produk isolasi limbah krustacea, mempunyai ikatan

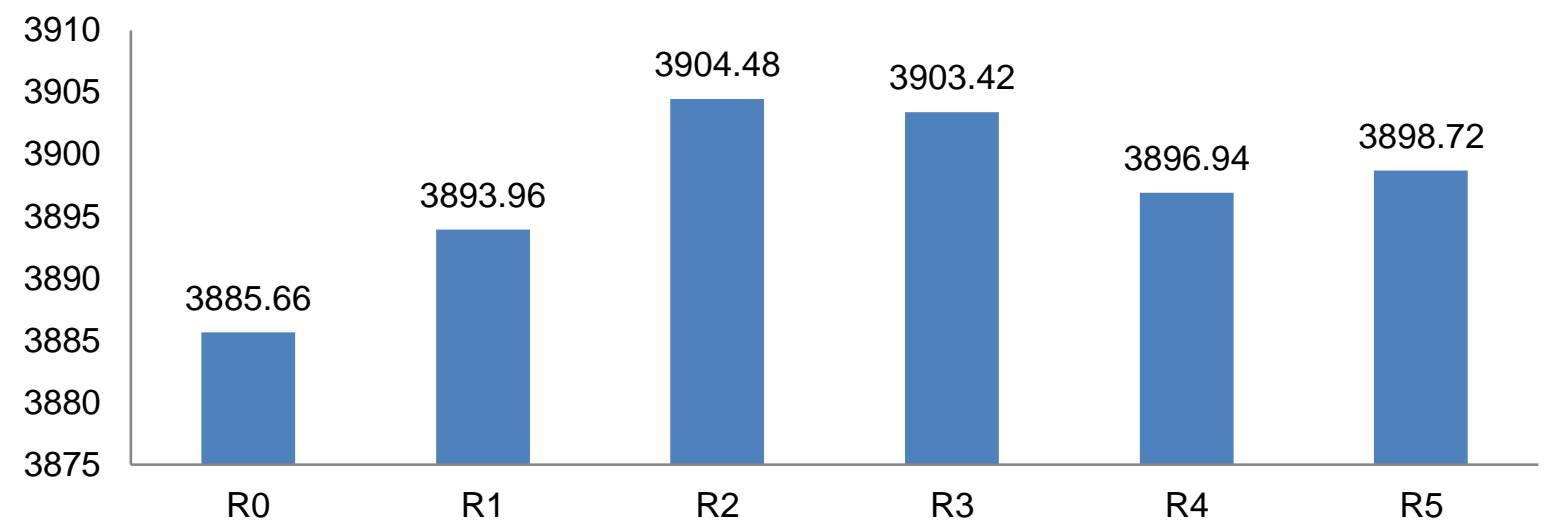

Gambar 1. Histogram Rataan Konsumsi Ayam Arab Selama Penelitian (7 Minggu)

gram/ekor/hari dengan kandungan protein 14-16 \% dan energy metabolisme $2400-$ $2500 \mathrm{kkal} / \mathrm{kg}$.

\section{Pengaruh Perlakuan Kitosan terhadap Hen Day Production}

Presentase hen day production perlakuan $\mathrm{R} 0=59,80$ persen, $\mathrm{R} 1=69,39$ persen, $\mathrm{R} 2=63,47$ persen dan $\mathrm{R} 3=71,23$ persen, $\mathrm{R} 4=68,77$ dan $\mathrm{R} 5=69,18$.

Hasil analisa uji statistik memperlihatkan bahwa penambahan kitosan dalam ransum tidak berpengaruh nyata untuk meningkatkan hen day (\%) (Gambar 2). Penyebab pemberian kitosan tidak berbeda $\beta$-glikosidik (Tolaimatea et al., 2003 dalam Kurniasih et al., 2011), yang sulit terurai dalam saluran pencernaan. 2) hewan monogastrik termasuk jenis hewan tidak mampu mencerna serat kasar, sehingga penambahan kitosan tidak memberikan pengaruh yang nyata terhadap peningkatan produksi (Adriani et al., 2018). Struktur kitosan yang keras bersifat tidak larut dalam air, sehingga tidak dapat mempengaruhi peningkatan penyerapan nutrien dalam saluran pencernaan. Hal ini disebabkan karena sejumlah cairan pencernaan yang disekresikan dalam lumen saluran pencernaan oleh kelenjer eksokrin yang terdapat disepanjang saluran pencernaan,

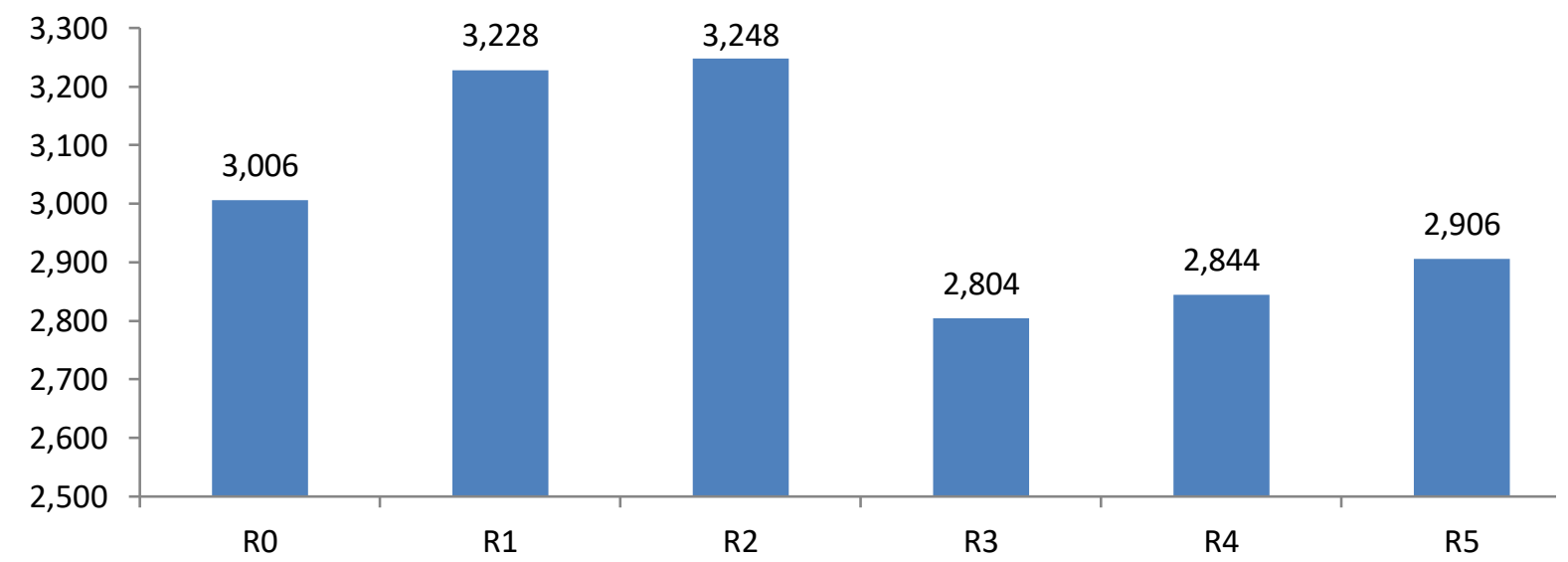

Gambar 2. Histogram Rataan Produksi Telur Ayam Arab Selama Penelitian (7 Minggu) 
belum mampu mendegradasi polimer kitosan menjadi monomer yang lebih sederhana. Akibatnya, gugus asam amino sebagai monomer dari kitosan belum bisa berdistribusi dalam peningkatan protein sebagai material utama telur ayam. Kelarutan kitosan yang rendah dalam saluran pencernaan tidak banyak membantu dalam mengoptimalkan peningkatan hen day production. Faktor ini memberi suatu pemahaman bahwa kitosan dalam penelitian ini tidak diarahkan untuk peningkatan hen day production.

\section{Pengaruh Perlakuan Kitosan terhadap Konversi Ransum}

Efisiensi penggunaan ransum dalam menghasilkan produksi telur termasuk indikator keberhasilan suatu usaha peternakan unggas petelur. Artinya banyak ransum yang digunakan dalam menghasilkan telur adalah sangat diperhitungkan. Agar diperoleh informasi tersebut maka perlu dihitung keefisienan penggunaan ransum, yaitu berapa $\mathrm{kg}$ bobot telur yang dapat dihasilkan dari satu kg ransum.

Berdasarkan hasil uji statistik tidak terdapat pengaruh perlakuan kitosan terhadap konversi ransum $(\mathrm{P}>0,05)$. Rataan konversi ransum ayam penelitian berkisar antara 2,804 - 3,248 (Ilustrasi 3). Rataan nilai konversi ransum untuk masing-masing perlakuan secara berturut - turut yaitu $\mathrm{R} 0=3,006 \mathrm{R} 1=$ $3,228 \quad \mathrm{R} 2=3,248 \quad \mathrm{R} 3=2,804 \quad \mathrm{R} 4=2,844$ $\mathrm{R} 5=2,906$.

Jumlah konsumsi ransum dan produksi telur, menunjukkan perbedaan yang tidak nyata akan memberikan hasil yang hampir sama terhadap konversi ransum. Menurut Subekti (2012) bahwa, konversi ransum merupakan ukuran efisiensi dalam penggunaan ransum. Semakin rendah nilai konversi ransum semakin efisien penggunaan dari ransum tersebut, karena semakin sedikit jumlah ransum yang dibutuhkan untuk menghasilkan telur dalam jangka waktu tertentu. Kitosan yang ditambahkan ke dalam ransum tidak mempengaruhi jumlah ransum yang dikonsumsi, karena sifatnya hanya sebagai pelindung nutrien ransum. Selain itu ada pengaruh dari struktur kitosan yang menyerupai serat kasar, merupakan polimer yang sulit terdegradasi dalam saluran pencernaan. Hal ini memberi dampak keterbatasan ternak ayam dalam mencerna. Akibat dari struktur kitosan tersebut, maka nutrien yang terserap untuk pembentukan

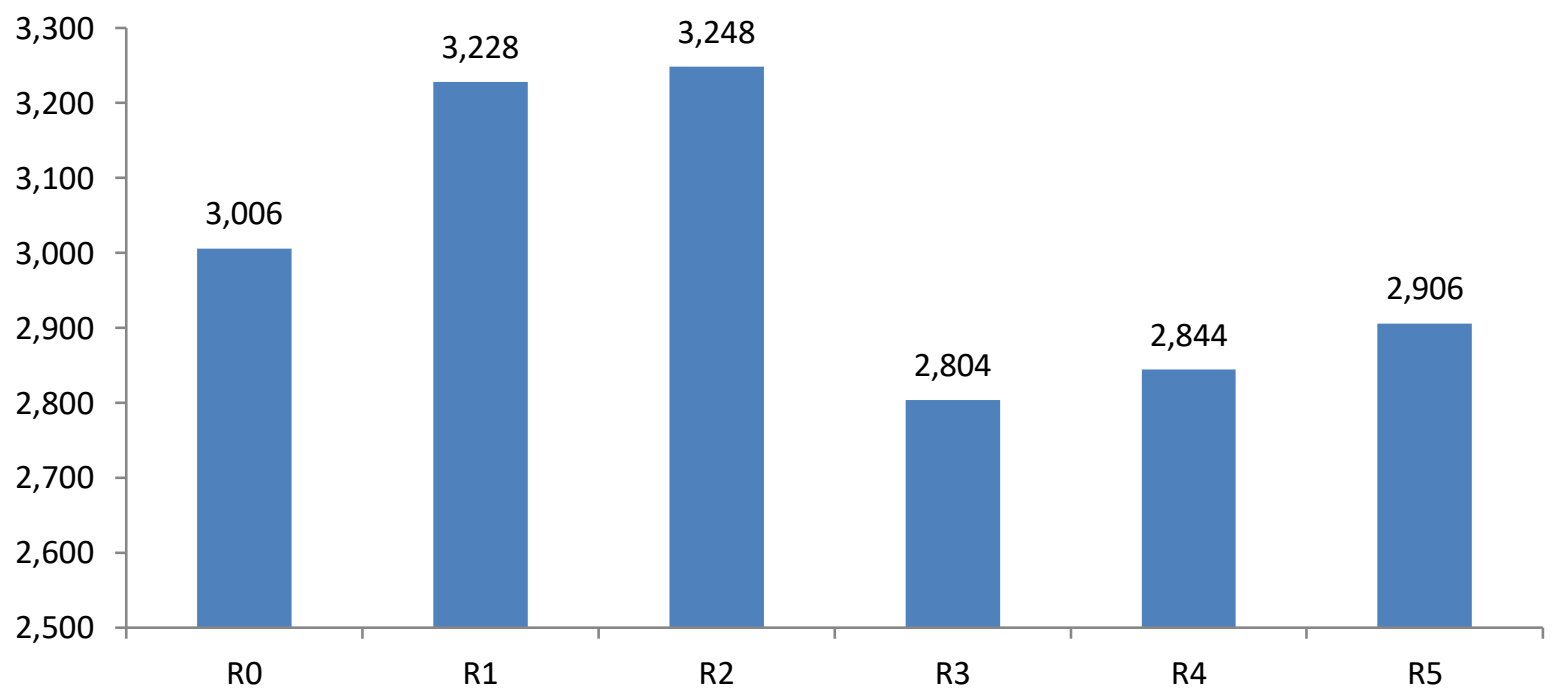

Gambar 3. Histogram Rataan Konversi Ransum Ayam Arab Selama Penelitian (7 Minggu 
telur relative akan sama sehingga jumlah dan bobot telur juga akan hampir sama. Jadi terdapat hubungan yang erat antara konsumsi ransum dengan bobot telur yang hampir sama, yaitu akan menghasilkan konversi ransum juga relative hampir sama. Pernyataan Sugiharto (2005) dalam Natalia et al. (2019) bahwa bahwa faktor yang mempengaruhi besar kecilnya konversi pakan meliputi umur, pakan, daya cerna ternak, juga senyawa radikal yang dihasilakan dari proses pencernaan (Mushawwir dan Latipudin, 2012; Mushawwir dkk., 2019), serta laju metabolism terkait mikroklimat (Suwarno dan Mushawwir, 2019), meskipun demikian tingkat kosumsi, adalah faktor yang sangat relevan dengan data penelitian ini. Ada indikasi bahwa perlakuan R3 (1,5\% kitosan) mempunyai efisiensi ransum terbaik, yaitu memerlukan 2,804 $\mathrm{kg}$ ransum untuk menghasilkan $1 \mathrm{~kg}$ telur. Angka konversi ransum ayam penelitian pada perlakuan R3 (1,5\% kitosan) ini dinilai sangat baik karena sesuai dengan pernyataan Scott et al. (1982) bahwa konversi pakan ayam petelur selama periode telur pertama maupun kedua berkisar antara 2,0-3,0.

\section{SIMPULAN}

Penambahan kitosan dalam ransum ayam petelur selama penelitian 7 minggu, menunjukkan peforma produksi yang berimbang untuk semua perlakuan, dan dosis $1,5 \%$ kitosan (R3) terindikasi akan menunjukkan peningkatan produksi jika dipelihara dalam waktu yang lebih lama

\section{UCAPAN TERIMAKASIH}

Terimakasih kepada kementrian riset teknologi pendidikan tinggi Universitas Sriwijaya atas bantuan dana dalam penelitian ini

\section{DAFTAR PUSTAKA}

Adriani, L., A. Mushawwir, B.R. Anastasia and B. Rahayu B. 2018. Effect of combination chitosan and turmeric powder (curcuma domestica val.) For improving blood lipid profile in broilers. Scientific Papers. Series D. Animal Science. LXI:225-229.

Dinana, A., D. Latipudin, D. Darwis dan A. Mushawwir. 2019. Profil Enzim Transaminase Ayam Ras Petelur Yang Diberi Kitosan Iradiasi. J. Nutrisi Ternak Tropis dan Ilmu Pakan 1:6-15.

Fan, H.P., M. Xie, W.W. Wang, S.S. Hou and W. Huang. 2008. Effect of dietary energy on growth performance and carcass quality of white growing pekin ducks from two to six weeks of age. Poult. Sci. 87:62-1164.

Huang RL, Y.L. Yin, G.Y. WU, T.J. Zhang, L.L. Li, M.X. Li, Z.R. Tang, J. Zhang, B. Wang, J.H. He and X.Z. Nie. 2005. Effect of Dietary Oligochitosan Suplementation on Ileal Nutrient Digestibility and Performance in Broilers. Poult. Sci . 84:1383-1388

Kurniasih, M. dan D. Kartika. 2011. Sintesis dan Karakterisasi Fisika-Kimia Kitosan. J. Inovasi. 5:42-48.

Mushawwir, A., Y.K. Yong, L. Adriani, E. Hernawan and K.A. Kamil. 2010. The Fluctuation Effect of Atmospheric Ammonia (NH3) Exposure and Microclimate on Hereford Bulls Hematochemical. J. of the Indon. Tropical Anim. Agric. 35:232-238.

Mushawwir, A., L. Adriani and K.A.Kamil. 2011. Prediction Models for Olfactory Metabolic and Sows\% RNAreticulocyt (RNArt) by Measurement of Atmospheric Ammonia Exposure and Microclimate Level. J. of the Indon. Tropical Anim. Agric. 36:14-20.

Mushawwir, A. dan D. Latipudin. 2012. Respon fisiologi thermoregulasi ayam ras petelur fase grower dan layer. Proseding seminar zootechniques for Indogeneous resources development, ISAA Fakultas Petenakan Universitas Diponegoro. Proceeding of National Seminar on Zootechniques. 1:23-27. Mushawwir, A., N. Suwarno dan A.A. Yulianti. 2019. Profil Malondial- 
dehyde (MDA) dan Kreatinin Itik Fase Layer yang Diberi Minyak Atsiri Garlic Dalam Kondisi Cekaman Panas. J. Ilmu dan Industri Peternakan 5:1-11.

Natalia, D., E. Suprijatna dan R. Muryani. 2019. Pengaruh Penggunaan Limbah Industri Jamu dan bakteri Asam Laktat (Lactobacillus sp) sebagai Sinbiotik untuk Aditif Pakan terhadap Performans Ayam Petelur Periode Layer. J. Ilmu-ilmu Peternakan 26:613.

Rukayadi, Y. 2002. Kitin Deasetilase dan Pemanfaatannya. Hayati. 9:130-134.

Sarwono, B. 2002. Ayam Arab Petelur Unggul. Penebar Swadaya. Jakarta.

Scott, M.L., M.C. Nesheir and R.J. Young. 1982. Nutrition of the Chicken. Ml Scott and Asociation. Itacha New York. Sofyan, A., E. Damayanti dan H. Julendra. 2008. Aktivitas Antibakteri dan Retensi Protein Tepung Cacing Tepung Tanah (Lumbricus rubellus) sebagai Pakan Imbuhan Dengan Taraf Penambahan Kitosan". JITV. 13:13-18.

Stee, R.G.D. dan J.H Torrie. 1991. Prinsip dan Prosedur Statistika. Suatu Pendekatan Biometrik. Alih Bahasa Bambang Sumantri. PT. Gramedia. Jakarta.

Subekti, E. 2012. Pengaruh Penambahan Vitamin C Pada Pakan Non Komersial Terhadap Efisiensi Pakan Puyuh Petelur. Mediagro. 8:1-8.

Suwarno, N. dan A. Mushawwir. 2019. Model Prediksi Metabolit Melalui Jalur Glikogenolisis Berdasarkan Fluktuasi Mikroklimat Lingkungan Kandang Sapi Perah. Jurnal Ilmu dan Industri Peternakan. 5:77-86.

Tanuwiria, U.T., A. Mushawwir dan A.A. Yulianti. 2007. Potensi pakan serat dan daya dukungnya terhadap populasi ternak ruminansia di wilayah kabupaten Garut. J. Ilmu Ternak. 7:1116. 